\title{
Leptin Receptor in Ram Epididymal Spermatozoa
}

\author{
Mohammad Roostaei-Ali Mehr, Reza Rajabi-Toustani, Rasool Motamedi-Mojdehi \\ Department of Animal Science, Faculty of Agricultural Sciences, University of Guilan, Rasht, Iran \\ Email: roostaei@guilan.ac.ir, rezarajabi.t@gmail.com,r.motamedimojdehi@gmail.com
}

Received 2012

\begin{abstract}
This experiment was designed to investigate leptin receptors (Ob-R and Ob-Rb) mRNA in ram epididymal spermatozoa by RT-PCR. Ten testes were obtained from abattoir and epididymal spermatozoa recovery was performed. To purify spermatozoa, motile sperm were isolated by the swim-up procedure. Total RNA was isolated from epididymal spermatozoa and placental cotyledon, as a positive control, and then they were purified. Specific bands (98 and 308 bp) for Ob-R and Ob-Rb were detected after RT-PCR in both epididymal spermatozoa and placental cotyledon. We may conclude that Ob-R and Ob-Rb mRNA are present in ram epididymal spermatozoa and leptin perhaps exerts physiological effects, as already demonstrated in human.
\end{abstract}

Keywords: Epididymal Spermatozoa; mRNA; Ob-R; Ob-Rb

\section{Introduction}

Leptin is a $16 \mathrm{kDa}$ protein and mainly secreted by white adipose tissue [1]. Leptin modulates different systems via neuroendocrine regulation, including adrenal, thyroid and gonadal axes. Other functions of leptin have been suggested recently in peripheral organs that leptin independently interacts with leptin receptor in peripheral tissue, as well as reproductive organs [2]. Recent observations in female suggest that leptin is involved in relaying energy status to reproduction [3-7]. Various studies have also pointed out a direct role of leptin in the control of testicular function, but its actual role in the regulatory network controlling male reproduction is still a matter of debate $[3,6,8]$.

To date, at least five Ob-R isoforms (Ob-Ra-e) have been cloned from rodents and exhibit widespread distribution both in central and peripheral tissues [6,9]. Alternative splicing of the Ob-R transcript results in the various products that vary in the length of the cytoplasmic region [10]. Three Ob-R isoforms, the long form (Ob-Rb), the middle form (Ob-Ra) and the short form (Ob-Rc) were cloned and sequenced in bovine and ovine $[11,12]$. Ob-Rb was reported in most of the farm animal tissues $[10,13]$.

It is known that animal and human models of leptin resistance and deficiency show a severe impairment of the reproductive function [6]. Leptin receptors are present in several cell types in the human, bovine and porcine male and female reproductive system $[6,14]$. Therefore, it is seemed that leptin could exert a direct effect on the gonads [2]. There is little information about the expression of leptin and leptin receptor in ruminant such as sheep. To fully understand the peripheral effects of leptin as a local factor, it is necessary to study the structure and peripheral tissue distribution of its receptors (Ob-R and $\mathrm{Ob}-\mathrm{Rb}$ ).

The aim of this experiment was to determine the expression of Ob-R and Ob-Rb mRNA in ram epididymal spermatozoa, providing evidence for a role of leptin in sperm physiology.

\section{Materials and Methods}

Ten testes were obtained from abattoir. In the laboratory, the caudal epididymis was isolated from testis. Epididymal spermatozoa were obtained by slicing and suspending of the caudal epididymal tissue in Petri dish containing $5 \mathrm{ml}$ Tris $(300 \mathrm{mM}$ tris (hydroxymethyl) aminomethane, $95 \mathrm{mM}$ citric acidmonohydrate, $28 \mathrm{mM} \mathrm{D}-(+)-G l u c o s e, 2000 \mathrm{IU} / \mathrm{ml}$ penicillin G and $0.4 \mathrm{mg} / \mathrm{ml}$ streptomycin, $\mathrm{pH}$ 7.0). The samples were agitated and incubated at room temperature for $10 \mathrm{~min}$; liquid phase containing epididymal spermatozoa was collected. A complete semen analysis was performed on each sample: sperm motility was $>65 \%$ with normal morphology $>65 \%$ and viability $>70 \%$. Motility, viability, normal morphology and sperm concentration were evaluated by microscopic visual method, one-step eosin-nigrosin staining and hematocytometer method, respectively. Recovered epididymal spermatozoa were pooled and centrifuged for $10 \mathrm{~min}$ at $700 \times \mathrm{g}$ at room temperature; the supernatant was removed. To purify spermatozoa, motile sperm were isolated by the swim-up procedure; $250 \mu$ l of semen were layered under $1 \mathrm{ml}$ of Tris diluent in each of $15 \mathrm{ml}$ centrifuge tubes. After incubation for $1 \mathrm{~h}$ at $37{ }^{\circ} \mathrm{C}$ in an atmosphere with $5 \% \mathrm{CO}_{2}, 750 \mu \mathrm{l}$ were removed from the top of each tube. The purity of spermatozoa was checked under a phase contrast microscope. Sperm were concentrated by centrifugation at $800 \times \mathrm{g}$ for $10 \mathrm{~min}$, the top of suspension was removed frozen in liquid nitrogen vapor and held in liquid nitrogen until RNA extraction.

Total RNA from placental cotyledon and epididymal spermatozoa were extracted according to Chomczynski and Saachi [15]. RNA samples were treated by DNAase I at $37^{\circ} \mathrm{C}$ for 30 min and then the enzyme was inactivated at $75{ }^{\circ} \mathrm{C}$ for $15 \mathrm{~min}$. After that Purity of RNA were determined by Biophotometer (Eppendorf, Germany) (OD 260/280 and 260/230 ratio) and visualized by electrophoresis on a $2 \%$ agarose gel, stained with $0.5 \mu \mathrm{g} / \mathrm{ml}$ ethidium bromide. RNA samples with no DNA bands 
after DNaseI treatment were used in RT-PCR reactions. Treated RNA was reverse transcribed to cDNA in a $20 \mu$ l final volume containing $1 \mu \mathrm{g}$ of extracted RNA, $200 \mathrm{ng}$ random hexamer and $0.5 \mathrm{mM}$ Deoxyribonucleotide triphosphate (dNTP) Mix. The mixture was heated at $65{ }^{\circ} \mathrm{C}$ for 5 min. $4 \mathrm{U}$ (in $1 \mu \mathrm{l}$ ) RNase inhibitor, RT buffer (50 mM Tris-HCL, $75 \mathrm{mM} \mathrm{KCL,} 3 \mathrm{mM}$ $\mathrm{MgCL}_{2}$ ), $10 \mathrm{mM}$ DTT and 200 units M-MuLV Reverse transcriptase (Fermentas, Germany) was added. This mixture was incubated for $60 \mathrm{~min}$ at $37{ }^{\circ} \mathrm{C}$. The prepared cDNA was incubated at $75{ }^{\circ} \mathrm{C}$ for $15 \mathrm{~min}$ to denature the M-MuLV-RT and then stored at $-20^{\circ} \mathrm{C}$.

Aliquots of $3 \mu \mathrm{l}$ of the first standard cDNA reaction were amplified in a $50 \mu \mathrm{l}$ reaction volume containing a final concentration of $1 \mathrm{X}$ PCR buffer, $2.5 \mathrm{mM} \mathrm{MgCl}_{2}, 0.2 \mathrm{mM}$ dNTP mix, $2 \mathrm{U}$ of recombinant Taq DNA polymerase (Fermentas) and 0.4 $\mathrm{mM}$ of primers. The cDNA primers to the leptin receptor sequence which recognizes all known splice variants of the leptin receptor (Ob-R) were '5 -TGCCACCAAA TACAACATATGACT-3' (182 to 205) and 5'-CTTAGTTTCA ACAACTGCCTCAGA-3' (256 to 279, Genbank AY278244), 98 bp product (Table 1). The cDNA primers to the long form of the ovine leptin receptor, Ob-Rb, were 5 -GATGAGATGGTG CCAACAACTA-3' (121 to 142) and 5'-TGGGTTTCTATTTC CCATGATC-3' (407 to 428, Genbank OAU62124), 308 bp product (Table 1).

PCR was performed on a Eppendorf thermal cycler (Mastercycler $^{\circledR}$ personal, Eppendorf, Germany using the following conditions: $94^{\circ} \mathrm{C}(4 \mathrm{~min}) 1$ cycle; $94^{\circ} \mathrm{C}(1 \mathrm{~min}), 55^{\circ} \mathrm{C}(1 \mathrm{~min})$, $72{ }^{\circ} \mathrm{C}$ (1 min) 45 cycles; $72{ }^{\circ} \mathrm{C}$ (10 min) 1 cycle. $15 \mu \mathrm{l}$ of each PCR product were subjected to electrophoresis in $1.5 \%$ aga- rosegel and stained with $0.5 \mu \mathrm{g} / \mathrm{ml}$ ethidium bromide.

\section{Results}

RT-PCR results are shown in Figure 1. Since the primers used for the amplification of Ob-R and Ob-Rb were designed from nucleotide sequences within one specific exon of gene, the isolated RNA samples were directly used in RT-PCR after DNaseI treatment to demonstrate the absence of genomic DNA contamination in the RNA probes (Figure 1, lanes 3 and 4). The 98 and 308 bp cDNA was never detected in RNA samples under study.

RNA isolated from placental cotyledon cells was used as positive control. RT-PCR with specific primers for Ob-R and Ob-Rb revealed a predicted RT-PCR product of $98 \mathrm{bp}$ in length (Figure 1, lanes 1 and 2). RT-PCR products were comparable in all examined sperm materials. Amplification of cDNA prepared with RNA isolated from epididymal spermatozoa showed the same predicted RT-PCR products of 98 and 308 bp for Ob-R and Ob-Rb (Figure 1, lanes 5 and 6).

\section{Discussion}

A growing interest is directed towards the presence of mRNA in mammalian ejaculated spermatozoa. Originally, these transcripts were hypothesized to be carried over from earlier stages of spermatogenesis. However new findings suggest that some of these transcripts can code for proteins essential in early embryo development [10]. Moreover, recent studies have shown that mRNA of leptin receptor is in human, swine and bovine spermatozoa [14,16,17].

Table 1. Sequence of the Primer Set Used for PCR.

\begin{tabular}{|c|c|c|c|c|c|c|}
\hline Gene & Primer $^{3}$ & Fragment size (bp) & AT & Cycles & GenBank & Reference \\
\hline Ob-R ${ }^{1}$ & $\begin{array}{l}\text { F: tgccaccaaatacaacatatgact } \\
\text { R: cttagtttcaacaactgcctcaga }\end{array}$ & 98 & $55^{\circ} \mathrm{C}$ & 45 & AY278244 & Thomas et al., 2001 [12] \\
\hline Ob-Rb ${ }^{2}$ & $\begin{array}{l}\text { F: gatgagatggtgccaacaacta } \\
\text { R: tgggtttctatttcccatgatc }\end{array}$ & 308 & $55^{\circ} \mathrm{C}$ & 45 & OAU62124 & Thomas et al., 2001 [12] \\
\hline
\end{tabular}

${ }^{1} \mathrm{Ob}-\mathrm{R}$ : total isoform of leptin receptor; ${ }^{2} \mathrm{Ob}-\mathrm{Rb}$ : long isoform of leptin receptor; ${ }^{3} \mathrm{~F}$ : Forward and R: Reverse primer.

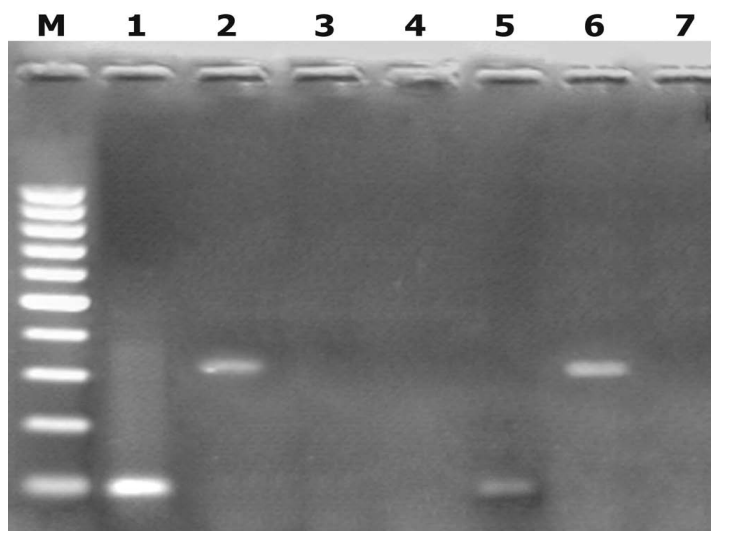

Figure 1. Representative Ob-R and Ob-Rb transcripts in epididymal spermatozoa and placental cotyledon. $M=$ molecular weight standards (100 bp DNA ladder, Fermentas). The numbers in the Figure indicate: (1) and (2) RT-PCR results of total RNA of placental cotyledon used as a positive control for Ob-R and Ob-Rb, respectively; (3) and (4) PCR results of sperm and placental cotyledon cell RNA, respectively; (5) and (6) RT-PCR results of total RNA of epididymal sperm for Ob-R and Ob-Rb, respectively; (7) blank. 
However, to our knowledge, this is the first time that the presence of mRNA of Ob-R and Ob-Rb in ram epididymal spermatozoa has been demonstrated. A recent study in pig has suggested that leptin receptor may induce transduction and molecular changes associated with sperm capacitation and survival [18]. These findings suggest that leptin, through leptin receptor, may play an important role in both sperm function and male fertility. Furthermore, as leptin interacts with insulin to regulate glycogen synthesis in mature spermatozoa, it might affect sperm motility, as already demonstrated in humans [8]. The presence of Ob-R mRNA in ram epididymal spermatozoa might suggest that leptin acts through leptin receptor to regulate spermatozoa energy expenditure in this species. At present, we do not have any information on the possible actions of leptin on ram spermatozoa.

\section{REFERENCES}

[1] L. A. Campield, F. J. Smith, and P. Burn, "The OB protein (leptin) pathway. A link between adipose tissue mass and central neural networks,” Horm. Metab. Res., vol. 28, pp. 619-631, Dec. 1996.

[2] I. J. Clarke, and B. A. Henry, "Leptin and reproduction,” Rev. Reprod., vol. 4, pp. 48-55, Jan. 1999.

[3] D. P. Shalev, Y. Soffer, and L. M. Lewin, "Investigation on the motility of human spermatozoa in a defined medium in the pre sence of metabolic inhibitors and of carnitine," Andrologia, vol. 18, pp. 368-375, Aug. 1986.

[4] C. Cunningham, D. K. Clifton, and R. A. Steiner, "Leptin's actions on the reproductive axis: perspectives and mechanisms," Biol. Reprod., vol. 60, pp. 216-222, Feb. 1999.

[5] K. Laud, I. Gourdou, L. Be Iair, D. H. Keisler, and J. Djinane, "Detection and regulation of leptin receptor mRNA in ovine mammary epithelial cells during pregnancy and lactation,” FEBS. Lett., vol. 463, pp. 194-198, Dec. 1999.

[6] M. Caprio, E. Fabrini, G. Ricci, S. Basciani, L. Gnessi, M. Arizzi, A. R. Carta, M. U. De Martino, A. M. Isidori, G. V. Frajese, and A. Fabbri, "Ontogenesis of leptin receptor in rat leydig cells," Biol. Reprod., vol. 68, pp. 1199-1207, Apr. 2003.

[7] S. C. Liefers, R. F. Veerkamp, M. F. W. Te Pas, Y. Chilliard and T. van der Lende. "Genetics and physiology of leptin in periparturient dairy,” Domest. Anim. Endocrinol., vol. 29, pp. 227-238,
Jul. 2005

[8] S. Aquila, M. Gentile, E. Middea, S. Catalano, and S. Andò, "Autocrine regulation of insulin secretion in human ejaculated spermatozoa,” Endocrinology, vol. 146, pp. 552-557, Feb. 2005.

[9] L. A. Tartaglia, M. Dembski, X. Weng, N. Deng, J. Culpepper, R. Devos, G. J. Richards, L. A. Campfield, F. T. Clark, J. Deeds, C. Muir, S. Sanker, A. Moriarty, K. J. Moore, J. S. Smutko, G. G. Mays, E. A. Wool, C. A. Monroe, and R. I. Tepper, "Identification and expression cloning of a leptin receptor, OB-R,” Cell, vol. 83, pp. 1263-1271, Dec. 1995.

[10] M. Haniu, T. Arakawa, E. J. Bures, Y. Young, J. O. Hui, M. F. Rohde, A. A. Welcher, and T. Horan, "Human leptin receptor. Determination of disulfide structure and N-glycosylation sites of the extracellular domain,” J. Biol. Chem., vol. 273, pp. 28691-28699, Oct. 1998.

[11] H. Kawachi, S. H. Yang, A. Hamano, T. Matsui, S. B. Smith, and H. Yano, "Molecular cloning and expression of bovine (Bos taurus) leptin receptor isoform mRNAs," Comp. Biochem. Physiol., vol. 148, pp. 167-173, Oct. 2007.

[12] L. Thomas, J. M. Wallace, R. P. Aitken, J. G. Mercer, P. Trayhurn, and N. Hoggard, "Circulating leptin during ovine pregnancy in relation to maternal nutrition, body composition and pregnancy outcome,” J. Endocrinol., vol. 169, pp. 465-476, Jun. 2001.

[13] L. A. Tartaglia, “The leptin receptor,” J. Biol. Chem., vol. 272, pp. 6093-6099, Mar. 1997.

[14] G. Nikbakht, M. Roostaei Ali Mehr, A. Baghbanzadeh, P. Tajik, C. Tamanini, and M. Emam, "Leptin receptor mRNA in bull ejaculated spermatozoa,” Reprod. Dom. Anim., vol. 45, pp. 237-242, Apr. 2010.

[15] P. Chomczynski, and N. Sacchi, "Single step method of RNA isolation by acid guanidinium hiocyanate-phenol-choloroform extraction,” Anal. Biochem., vol. 162, pp. 156-159, Apr. 1987.

[16] T. Jope, A. Lammert, J. Kratzsch, U. Paasch, and H. J. Glander, "Leptin and leptin receptor in human seminal plasma and in human spermatozoa,” Int. J. Androl, vol. 26, pp. 335-341, Dec. 2003.

[17] M. De Ambrogi, M. Spinaci, G Galeati, and C. Tamanini, "Leptin receptor in boar spermatozoa,” Int. J. Androl, vol. 30, pp. 458-461, Oct. 2007.

[18] S. Aquila, V. Rago, C. Guido, S. Zupo, I. Casaburi, and A. Carpino, "Leptin and leptin receptor in pig spermatozoa: evidence of their involvement in sperm capacitation and survival," Reproduction, vol. 136, pp. 23-32. Epub. 